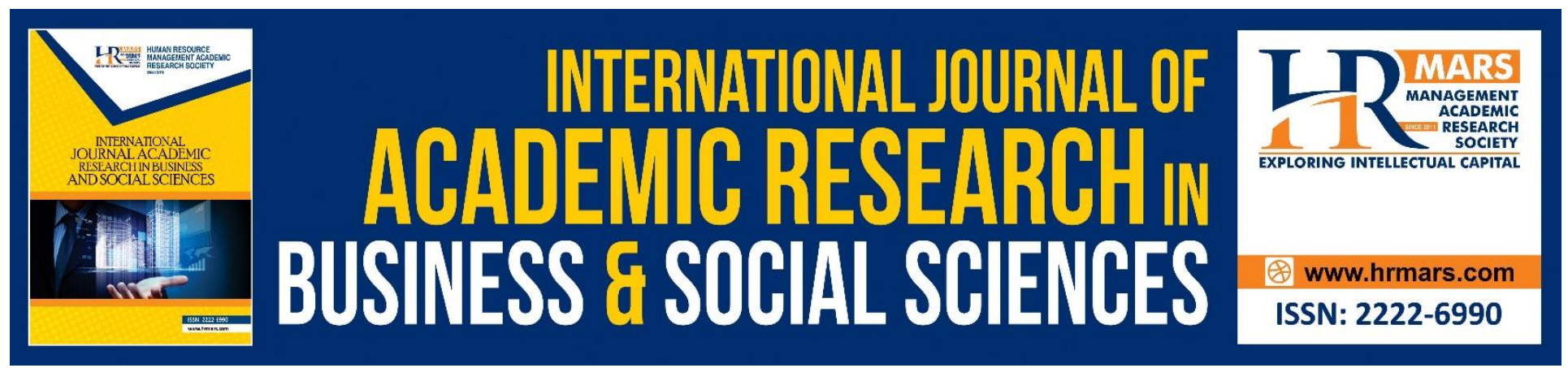

\title{
Risk Identifications of Postharvest Handling in Pineapple Crop that Affecting the Fruits Quality
}

Nur Farhanawati Wahab, Fatin Khairuddin

To Link this Article: http://dx.doi.org/10.6007/IJARBSS/v10-i9/7858

DOI:10.6007/IJARBSS/v10-i9/7858

Received: 06 June 2020, Revised: 10 July 2020, Accepted: 17 August 2020

Published Online: 22 September 2020

In-Text Citation: (Wahab, \& Khairuddin, 2020)

To Cite this Article: Wahab, N. F., \& Khairuddin, F. (2020). Risk Identifications of Postharvest Handling in Pineapple Crop that Affecting the Fruits Quality. International Journal of Academic Research in Business and Social Sciences. 10(9), 671-680.

Copyright: (c) 2020 The Author(s)

Published by Human Resource Management Academic Research Society (www.hrmars.com)

This article is published under the Creative Commons Attribution (CC BY 4.0) license. Anyone may reproduce, distribute, translate and create derivative works of this article (for both commercial and non-commercial purposes), subject to full attribution to the original publication and authors. The full terms of this license may be seen

at: http://creativecommons.org/licences/by/4.0/legalcode

\section{Vol. 10, No. 9, 2020, Pg. 671 - 680}

Full Terms \& Conditions of access and use can be found at http://hrmars.com/index.php/pages/detail/publication-ethics 


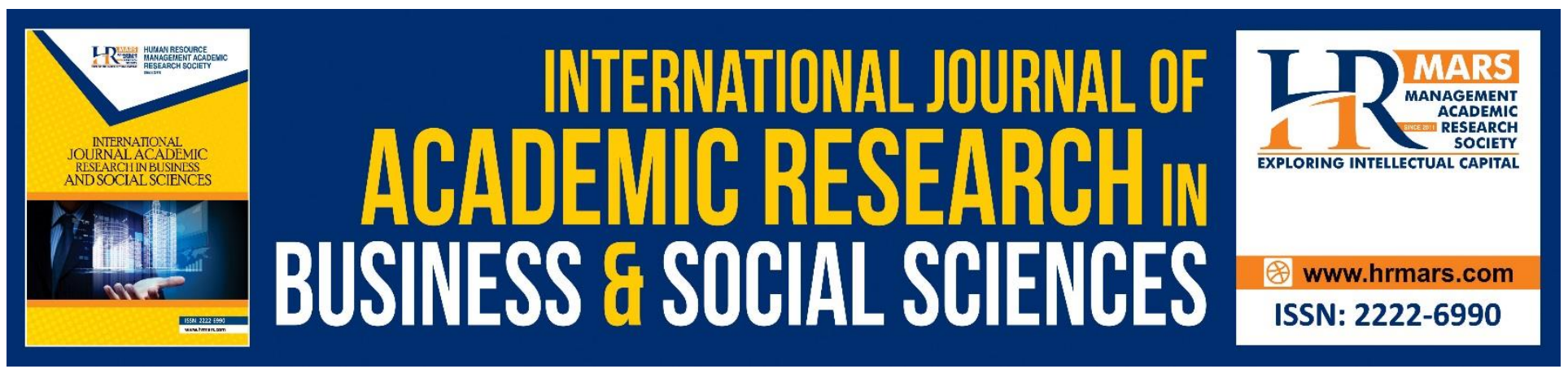

\title{
Risk Identifications of Postharvest Handling in Pineapple Crop that Affecting the Fruits Quality
}

\author{
Nur Farhanawati Wahab, Fatin Khairuddin \\ Faculty of Plantation and Agrotechnology, Universiti Teknologi Mara (UiTM), Cawangan Melaka \\ Kampus Jasin. \\ Email:wahabfarhana97@gmail.com,fatinkhairuddin@uitm.edu.my
}

\begin{abstract}
Pineapples is a tropical fruit from East Area of South America. Its scientific name is Ananas Comosus. This tropical fruit were planted in peat soil and its quality different because of a few factors such as climate, cultivation technique, harvesting time, storage, and the transportations facilities (Hossain MF, 2016). Moreover, pineapples also needed a good management in post-harvest handling to maintain and improve its quality. Highest quality of the Pineapples can give a satisfaction to the consumers during purchased it. Purposed of this study is to identify the risk in the postharvest handling of pineapples crops which can influenced the pineapples quality. This study was involved 70 farmers that located at Kluang and Muar, Johor. During this study, a set of questionnaires were distributed to the respondents. Then, interpret and analysis the data by using Statistical Package for Social Science (SPSS) by involving data analysis which are descriptive data and regression analysis. The results shown that common risk happened because of skill workers, packaging, mechanical damage and transportations. The most dominant risk is skills workers which influences the pineapples quality with the Beta value is 0.327 , followed by transportations which is 0.267 . As a conclusion, all of the variables in independent variables can be the risk that can affect and reduced the pineapples quality during the post-harvest handling and activities.
\end{abstract}

Keywords: Pineapples, Risk, Post-Harvest, Farmer's Skills, Packaging, Transport Management, Mechanical Damage.

\section{Introductions}

Pineapple is a tropical fruit that were from the East Area of South America. Its scientific name is Ananas Comosus. Proper postharvest handling must be made because based on (Anis Ahmed Mirza et al., 2016) stated that the reducing of the pineapple productions was mostly influenced by the poor post-harvest handling. Post-harvest are the activities that must be consider after the harvesting process. Post-harvest handling very important in ensuring the fruits quality. Examples of the postharvest activities are such as harvesting, handling, storage, processing, packaging, transport, and lastly is marketing (Geoffrey, et.al, 2002). Post-harvest handling of the pineapples starts after the harvesting process. Hence, a few factors that can cause the quality of pineapples loss such as rough 
handling, failure of sorting and grading, inadequate packing, improper pre-cooling and insufficient temperature regulation (Mirza et al., 2016). Hence, the decreasing of the post-harvest losses and improving the pineapples quality are important if the demand for the pineapples highest from current productions. Mohammed Kasso et al., 2016 also stated that the significant post-harvest degradation and deterioration of the quality of the horticultural crops such as pineapples occurred mostly during harvesting accompanied by distribution, transportation and storage. Based on the (Lotis, 2016) stated that highest loss of pineapples due to the lack of post-harvest handling about $30 \%$ to $40 \%$. So, a proper post-harvest handling must be taken to reduce the risk of post-handling. Besides, quality is always synonymous with an outstanding look, freshness, taste, colour and scent of pineapple, besides being free of injuries and disorders.

\section{Research Objectives}

The research objectives of this risk in post-harvest handling are as below:

1. To identify the risk in post-harvest handling of pineapple.

2. To determine the major risk that affects pineapple quality.

3. To suggest the solutions for the most dominant risk that affecting pineapples Quality

\section{Literature Review \\ Workers Skill}

The factors influenced risk in post-harvest handling of Pineapples are farmer's skills. Farmers skills very important to avoid from the post-harvest loss which can lead the quality of fruits will decline. Unskilled farmers or pineapple growers that handling the post-harvest activities is a risk because based on (Atanda et al., 2011) stated that lack of skills in processing, packing and storage can cause the post-harvest loss. Hence, it will lead to the reducing of pineapples quality. Not only that, unskilled farmers also will cause the appearance of the pineapples looks bruised and have a dark spot due to the lack handling of post-harvest. Hossain et al., 2015 also stated that post-harvest loss and the quality of pineapple declined because of the lack of awareness, knowledge and skills that related to the post-harvest activities.

\section{Packaging}

Inappropriate packaging will lead to a postharvest handling activity that can reduce the quality of pineapples. Hence, during the packaging process, pineapples should be packed based on the size, colour and shaped. Not only that, based on (Anis et al., 2016) stated that net weight pineapple fruits 10 to $15 \mathrm{Kg}$ are packed in a box of varying sizes to avoid from any injury of the shell or crown. Anis et al., 2016 also stated that, pineapples must be immediately packed after the harvesting process to avoid from the water loss then caused pineapples shrink. Moreover, pineapples must be packed in 6 $\mathrm{Kg}$ during the smaller size and up to $20 \mathrm{Kg}$ when pineapples big to avoid from the pineapples damaged. Packaging must be stable to avoid many violations between the pineapples during transport. However, based on the Mohammed Kasso et al., 2016 stated that packaging is a risk which must be overcome by using the plastic bags and wooden boxes of linear to avoid the moisture loss of the crops. Besides, packaging of mix different ripeness index of pineapples will reduce the fruit quality. 
INTERNATIONAL JOURNAL OF ACADEMIC RESEARCH IN BUSINESS AND SOCIAL SCIENCES Vol. 10, No. 9, 2020, E-ISSN: 2222-6990 @ 2020 HRMARS

\section{Transportation}

Based on the (Das et al., 2017) stated that the transportations with poor handling and use of improper marketing processes during transportation often lead to the loss. Hence, automatically it will cause the pineapples quality. Moreover, the transportation without proper control of temperature in refrigerated container that were equipped with filters that functions as the ethylene gas controller can reduce the quality of pineapples (Medina and Garcia, 2005). So, farmers or growers must take serious during handling post-harvest activities especially during transport pineapples either from field to the operations house or to the factory for product processing. Based on the (Wijesinghe et al., 2002) stated that when the pineapples be compressed during the transport, it will cause the pineapples damage and bruise. Highest bad impact during transport pineapples can happen if the air pressure in the truck's tiers highest. During transport pineapples, the speed of the truck or transportation must be considered based on a few factors such as quality of trailer, grade or quality of the road. Hence, the post-harvest handling especially during long distance transport and market of pineapples must be handle wisely to maintain the quality and remain in excellent conditions when reached the destinations (Abdullah, 2011).

\section{Mechanical damage}

Mechanical damage can cause the fruits become a bruise during the harvesting process and along the post-harvest handling (Hussein et al., 2019). So, a proper handle must be taken during the postharvest handling to avoid from the pineapples damage. Pineapple is exposed to spoilage during postharvest due to mechanical damage, physiological disturbances, infections, lack of moisture and the normal process of degradation (Abdullah, 2011). Next, mechanical injuries are a risk in the postharvest handling because based on (Saavedra et al., 2013) stated that compression injuries (major), cutting impacts led to the fruit quality loss. During pineapples be stored, it requires a suitable ventilations, moisture or humidity and temperature. Hence, farmers and growers also must handle them wisely to avoid from the mechanical damaged that will cause the pineapples water loss, shrink, weight loss, discoloured, watery and diseased infections. Not only that, mechanical damage also causes pineapple bruising or puncturing due to inadequate handling, falling or abrasion can lead in localized softening areas and secondary microbial infection may develop.

\section{Research Methodology Location of Study}

Location of study were purposely to get a place that was functioning as in conducting of this study. In this study, the locations that were chosen is at Malaysian Pineapples Industry Board (MPIB) that were located at P/S 19, Jalan Abas, 82000 Pontian, Johor and No.314, Jalan Kamariah, Taman Sri Tanjung, 84000 Muar, Johor. This placed was chosen because of it has sufficient information that I need for my study. Not only that, during my survey at that place, I was helped by three staffs of the firms. During this survey, it was distributed into two distinct which are Kluang and Muar.

\section{Population of Study and Sample Size}

The populations of the smallholders only focused on a few of them that were suitable with my study. Total populations of the smallholders that were involved are 85 persons. The populations were chosen based on their availability during the day that the survey was conducted and requirements in the questionnaire. In determining the sample size of the populations for this survey are by using the 
INTERNATIONAL JOURNAL OF ACADEMIC RESEARCH IN BUSINESS AND SOCIAL SCIENCES Vol. 10, No. 9, 2020, E-ISSN: 2222-6990 @ 2020 HRMARS

Krejcie and Morgan table. Krejcie and Morgan (1972) were came out with a table that purposely use to determine the sample size of the populations for the survey process. Krejcie and Morgan tables also constructed by using the formula to determine the sample size. The populations smallholders at the place that be chosen is 85 . So, sample size that must be achieved are 70 persons.

\section{Data Collection Method}

In this study, the primary data collection method was used by using qualitative method which is commonly not involve with the numbers or mathematical calculations. Data collections method and analysis of the quantitative include the questionnaire with close-ended questions, mean, methods of regression and regressive. The method of this research that be used was surveyed through distributed questionnaire. During conducting this survey, an interview with the respondent were used in getting the data by giving the questionnaire to the respondents. There were two sections which are Section A and Section B. Section A were focused on the demography of the respondents. While, in the Section B focused on the risk in the postharvest handling's activities that affecting the pineapples quality. Simple randomly method was used for this study because in this case, each person is selected by possibility and each member of the population has the same chance or the possibility of being chosen. It also one way of getting a random sample is to know the number of each person in a population, then using a table of random numbers to determine which people to include.

\section{Theoretical Framework}

\section{Independent variable}

\begin{tabular}{|c|}
\hline Transportation \\
\hline Mechanical injury \\
\hline \hline Packaging \\
\hline
\end{tabular}

\section{Dependent variable}

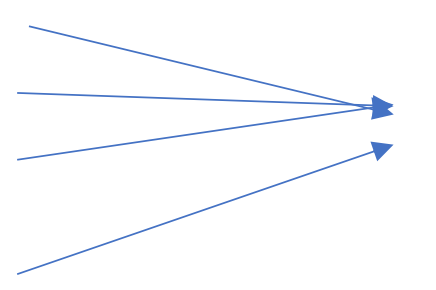

Fruits quality

The study was focused on the many risks in post-harvest handling that affecting the pineapples quality. Getting the post-harvest handling in a proper way was the best solutions in reducing the risk to the pineapple's quality. It is necessary that the farmers understand and take seriously on the different risk that affect the pineapples quality in the post-harvest handling and activities. Therefore, theoretical framework for independent variables in the study that are affecting the fruit quality are transportation, skill of workers, mechanical injury and packaging. For instance, lack of smallholder's skills, inappropriate packaging, low transport management and lastly mechanical injury in postharvest handling has been conducted.

\section{Results and Discussions}

\section{Descriptive Analysis for Demographic Factor}

The table below shows about the descriptive analysis of demographic factor. There were six types of respondents which are age, experience, race, area of land, yield obtained and district. The most dominant age is above 11 years. Respondents of above 11 years were having the highest experience which is from Malay. Next is farmers mostly had the area of land one acre to 10-acre with the highest yield obtained per month is zero to 500 tonnes. The highest respondents from Kluang district. 
INTERNATIONAL JOURNAL OF ACADEMIC RESEARCH IN BUSINESS AND SOCIAL SCIENCES Vol. 10, No. 9, 2020, E-ISSN: 2222-6990 @ 2020 HRMARS

Table 1: Descriptive analysis of demographic factor

\begin{tabular}{|c|c|c|c|c|c|}
\hline Respondents & Demographic & Frequency & $\begin{array}{l}\text { Percentage } \\
(\%)\end{array}$ & Minimum & Maximum \\
\hline \multirow[t]{4}{*}{ Age } & Under 1 years & 2 & 2.6 & \multirow[t]{4}{*}{1.00} & \multirow[t]{4}{*}{4.00} \\
\hline & 2 years - 5 years & 17 & 22.4 & & \\
\hline & 6 years -10 years & 26 & 34.2 & & \\
\hline & Above 11 years & 31 & 40.8 & & \\
\hline \multirow[t]{4}{*}{ Experience } & Under 1 years & 2 & 2.6 & \multirow[t]{4}{*}{1.00} & \multirow[t]{4}{*}{4.00} \\
\hline & 2 years - 5 years & 17 & 22.4 & & \\
\hline & 6 years - 10 years & 26 & 34.2 & & \\
\hline & Above 11 years & 31 & 40.8 & & \\
\hline \multirow[t]{3}{*}{ Race } & Malay & 43 & 56.6 & \multirow[t]{3}{*}{1.00} & \multirow[t]{3}{*}{3.00} \\
\hline & Chinese & 31 & 40.8 & & \\
\hline & Indian & 2 & 2.6 & & \\
\hline \multirow[t]{4}{*}{ Area of land } & 1 acre - 10 acre & 63 & 82.9 & \multirow[t]{4}{*}{1.00} & \multirow[t]{4}{*}{4.00} \\
\hline & 11 acres - 20 acre & 2 & 2.6 & & \\
\hline & $\begin{array}{l}30 \text { acres }-40 \\
\text { acres }\end{array}$ & 5 & 6.6 & & \\
\hline & $\begin{array}{l}50 \text { acres and } \\
\text { above }\end{array}$ & 6 & 7.9 & & \\
\hline \multirow{4}{*}{$\begin{array}{l}\text { Yield } \\
\text { obtained }\end{array}$} & $0-500$ & 64 & 84.2 & \multirow[t]{4}{*}{1.00} & \multirow[t]{4}{*}{4.00} \\
\hline & $600-1000$ & 4 & 5.3 & & \\
\hline & $2000-7000$ & 7 & 9.2 & & \\
\hline & $8000-13000$ & 1 & 1.3 & & \\
\hline \multirow[t]{2}{*}{ District } & Kluang & 70 & 92.1 & \multirow[t]{2}{*}{1.00} & \multirow[t]{2}{*}{4.00} \\
\hline & Muar & 6 & 7.9 & & \\
\hline
\end{tabular}

Descriptive analysis for risk identifications of pineapples in postharvest handling

Table 2: Mean of risk that affecting pineapples during postharvest activities

\begin{tabular}{|l|c|}
\hline Elements & Mean \\
\hline Transportations & 4.7149 \\
\hline Mechanical injury & 4.5827 \\
\hline Packaging & 4.6540 \\
\hline Farmers Skills & 4.6403 \\
\hline
\end{tabular}

First objective is to identify the risk in post-harvest handling of pineapple. Descriptive analysis is conducted to answer first objective. From table 2, it shows that transportations (4.7149) have a transportation is the highest mean among all the variables which interpreted that most of the respondents choose strongly agreed that transportation is the risk that affecting the fruits quality. Based on the (Wijesinghe et al., 2002) stated that when the pineapples are compressed during the 
INTERNATIONAL JOURNAL OF ACADEMIC RESEARCH IN BUSINESS AND SOCIAL SCIENCES Vol. 10, No. 9, 2020, E-ISSN: 2222-6990 @ 2020 HRMARS

transport, it will cause the pineapples damage and bruise. Second factor that be the risk during the postharvest handling of pineapples is packaging (4.6540).

Anis Ahmed Mirza et al., 2016 also stated that pineapples must be immediately packed after the harvesting process to void from the water loss than caused pineapples shrink. Next is a farmer's skills (4.6403) because skills in post-harvest treatments also needed because based on (Tsado et al., 2013) stated that it can relieve chilling damage and improve shelf-life while preserving quality pineapple produce. Lastly, mechanical injury (4.5827) because of mechanical injuries are a risk in postharvest handling because based on (Juan Saavedra et al., 2013) stated that compression injuries (major), cutting impacts led to the fruit quality loss.

\section{Multiple Regression}

Table 3: ANOVA table from Regression

\begin{tabular}{|l|l|r|r|r|}
\hline Model & R & R Square & Adjusted R Square & \multicolumn{1}{c|}{ Std. Error of the Estimate } \\
\hline 1 & $.551^{\mathrm{a}}$ & .303 & .264 & .28388 \\
\hline
\end{tabular}

a. Predictors: (Constant), MeanPackaging, MeanTransportation, MeanMechanicallnjury, MeanSkillWorkers.

b. Dependent Variable: MeanQualityPineapple

\begin{tabular}{|c|c|c|c|c|c|c|}
\hline \multicolumn{7}{|c|}{ ANOVA $^{a}$} \\
\hline & del & Sum of Squares & $\mathrm{df}$ & Mean Square & $\mathrm{F}$ & Sig. \\
\hline & Regression & 2.493 & 4 & .623 & 7.734 & $.000^{b}$ \\
\hline & Residual & 5.722 & 71 & .081 & & \\
\hline & Total & 8.215 & 75 & & & \\
\hline
\end{tabular}

a. Dependent Variable: MeanQualityPineapple

b. Predictors: (Constant), MeanPackaging, MeanTransportation, MeanMechanicallnjury, MeanSkillWorkers

The coefficient of multiple determine is 0.303 , therefore about $30.3 \%$ of the variation in $\mathrm{Y}$ is explained by $X_{1}$. ANOVA table above shows both variables which are independent variable and dependent variable. The dependent variable is quality of pineapples while, the independent variables or predictors are packaging, transportation, mechanical injury and skill workers. Not only that, in this tables, it shows the value of significant. The value that had less than 0.05 was significant. Hence, in the ANOVA table above shows that the significant value is 0.000 . So, it meant that packaging, transportation, mechanical injury and skill workers have the statically significant different due to its significance value less than 0.05 . 
INTERNATIONAL JOURNAL OF ACADEMIC RESEARCH IN BUSINESS AND SOCIAL SCIENCES Vol. 10, No. 9, 2020, E-ISSN: 2222-6990 @ 2020 HRMARS

Table 4: Coefficient table for Regression

\begin{tabular}{|c|c|c|c|c|c|}
\hline \multirow[b]{2}{*}{ Model } & \multicolumn{2}{|c|}{ Unstandardized Coefficients } & \multirow{2}{*}{$\frac{\text { Standardized Coefficients }}{\text { Beta }}$} & \multirow[b]{2}{*}{$\mathrm{t}$} & \multirow[b]{2}{*}{ Sig. } \\
\hline & B & Std. Error & & & \\
\hline 1 (Constant) & .283 & .924 & & .306 & .761 \\
\hline Skill Workers & .476 & .178 & .327 & 2.682 & .009 \\
\hline Transportation & .368 & .144 & .269 & 2.555 & .013 \\
\hline Mechanical Injury & .108 & .103 & .126 & 1.057 & .294 \\
\hline Packaging & -.056 & .117 & -.049 & -.481 & .632 \\
\hline
\end{tabular}

From the above output, the regression equation is: $y=0.283+0.327 X_{1}+0.269 X_{2}+0.126 X_{3}-0.049 X_{4}$. Based on the results above, the most dominants variable is skill workers. So, it meant that skilled workers give the most impact on the quality of pineapples during handling the post-harvest activity. Hence, overall, from the regression results, it can be concluded that skill workers gave a huge impact on post-harvest handling if it was neglected. It also can be proved from the previous study by (Saeed et al., 2010) stated that the unskilled workers can damage the skin of pineapple during the grading process then will causes the bacteria growth. Not only that, based on (V.Indra and K. P. Sudheer., 2007) stated that during post-harvest activities such as during sorting must be handled with high skills and suitable facilities to take care of the fruit quality and trace the defect fruits.

Moreover, based on the table 4 shows that the influencer risk for pineapple's quality is skill workers and transportations. The results show skill workers beta value is 0.327 and significant value is 0.009 . Transportations result beta value is 0.269 and $p$ value is 0.013 . Hence, both risks were significant impacts on pineapples quality with most dominant risk is skill workers. But mechanical injury and packaging no significant impacts of pineapple's quality due to the significant value is more than 0.05 . Mechanical injury beta value is 0.126 and significant value is 0.294 . Next, packaging beta value is 0.049 and significant value is 0.632 . Suggestion of solutions of Pineapples Quality

\section{Solutions for the Dominant Risk that Affected Pineapple Quality}

Based on the results above, the most dominant risk that happened among the pineapple industry between the farmers is skill in managed the post-harvest handling. So, there were four types of solutions to solve this major risk. All the solutions were based on two sources which are solution one to solution three from the results in chapter four and second sources is a solution four that make based on a few different previous studies. Mostly farmers agreed that lack of skills during handling the postharvest activities is a risk in the field. Hence, in the survey that had conducted with the mean 4.8421, farmers agreed that they must know the actual pineapple's maturity indices to make sure the fruits can be stored for a long time during the post-harvest process until the customers desires to eat the pineapples. Since the highest mean, 4.9605 of the farmers agreed that skill handler can reduce the pineapples injury during performing the postharvest activities, government such as MPIB, must make a seminar for the farmers on how to build their skills during handling the post-harvest handling.

Based on the previous study stated that by delivering the skills and knowledge to the farmers in postharvest handling, it can increase productivity of farmers in handling post-harvest activities and can enhance the quality of the fruits. For instance, in this study, they had made the MIVARF training 
programmed by exposing the farmers with the different post-harvest skills and other activities such as providing training on climate-resilient agriculture especially in food processing. Not only that, farmers also must be exposed with the skills in using the latest technology such as Modified Atmosphere Packaging (MAP) to maintain fruit quality and extend the shelf-life and other technology for instance in applying the ethylene to improve and delay ripening (Armachius James et al., 2017). Hence harvester must have skills during twisting and plugging-off the pineapples because based on (Abdullah, 2011) stated that when it done without carefully, it can cause the pineapples bruising.

\section{Conclusion}

As a conclusion, all of the variables in independent variables can be the risk that can affect and reduced the pineapples quality during the post-harvest handling and activities. Next, the risk that can affect the pineapple quality are farmer's skills, packaging, transportations and lastly is mechanical injury. So, an effective way must be conducted to control all this risk. The most dominant risk that can affect the pineapple quality is farmer's skills which can lead to the lowest pineapple quality if it was neglected. Hence, it happened when the farmers do not get sufficient knowledge, not be exposed more about post-harvest handling and training which can contribute to the reduction of pineapples quality. Not only that, transportation also is a quite risky that leads to the lowest pineapple's quality. Transportation is a second dominant risk after farmer's skill which can contribute to the quality of pineapples during the post-harvest handling.

\section{Theoretical and Contextual Contribution}

The study is about the risk of the post-harvest handling towards the pineapple's quality. There were many advantages and benefits from this study that can be implied in the pineapple's industry. Hence, it was purposely to exposed the farmers or smallholders about the risk during the post-harvest handling if they didn't do it wisely. Moreover, it also can increase and meet the demand of the pineapples productions in the market by reducing the post-harvest losses. For examples, when we handle a proper way during the packaging, or transport the pineapples, it will make the pineapple's quality in a good condition. Not only that, it also can avoid from the pineapples damaged and maintain the shelf-life of the pineapples during the long journey. Not only that, lack of skills such as in determining the maturity indices of the pineapples will cause the fruit bruises. Lastly, by considering all the risk during the post-harvest handling is that it has the capabilities to meet food requirements of a growing population by eliminating the losses and making the pineapples freshest.

\section{References}

Abdullah, H. (2011). Quality Maintenance of Pineapple in Postharvest Handling. 6.

Anis, A. M., Senthilkumar, S., \& Shanmugasundaram S. (2016). A review on trends and approaches in post-harvest handling of pineapple. Chemical and Pharmaceutical Sciences, ISSN:0974-2115.

Atanda, S. A., Pessu P. O., Agoda, S., Isong, I. U., Ikotun, I. (2011). The concepts and problems of postharvest food losses in perishable crops. Food Science, 5 (11) pp. 603-613, 11.

Filippone, P. T. (2019). what is pineapple? Retrieved from https://www.thespruceeats.com/historyof-the-pineapple-1807645.

Geoffrey, C., Mrema, Rossa, S. R. (2002). Status of the postharvest sector and its contribution to agricultural development and economic growth. 9th JIRCAS International Symposium, 13-20, 9. 
INTERNATIONAL JOURNAL OF ACADEMIC RESEARCH IN BUSINESS AND SOCIAL SCIENCES

Vol. 10, No. 9, 2020, E-ISSN: 2222-6990 @ 2020 HRMARS

Hossain, Bepary, R. H. (2015). Post-harvest handling of pineapples: A key role to minimize the postharvest loss. International Journal of Recent Scientific Research Research, 6, 6069-6075.

Hossain, M. F. (2016). World pineapple production: an overview. vol 16. no 4, 14. Retrieved from https://www.ajol.info/index.php/ajfand/article/view/149223/138722

https://biomedres.us/pdfs/BJSTR.MS.ID.002448.pdf

James, A., Zikankuba, V., and Yildiz, F. (2017). Postharvest management of fruits and vegetable. A potential for reducing poverty, hidden hunger and malnutrition in sub-Sahara Africa. Cogent Food \& Agriculture, Vol. 3 No. 1, pp. 1-13., 13.

Joy, P. P., and Rajuva, R. T. A., Vazhakulum, Muvattupuzha, Ernakulam, and Kerala. (2016). Harvesting and post-harvest handling of pineapple. 25.

Juan, S., Del, A., Lilia, S. H., and Ricardo, A. K. (2013). Compression Damage as The Principal Factor in Mechanical Injury of Pineapple Postharvest. 9.

Kader, A. A., and Kitinoja, L. (2002). Small-scale postharvest handling practices: a manual for horticultural crops. Fourth edition. Davis: University of California.

Kitinoja, L., and AlHassan, H. Y. (2012). Identification of Appropriate Postharvest Technologies for Small Scale Horticultural Farmers and Marketers in Sub-Saharan Africa and South Asia - Part 1. Postharvest Losses and Quality Assessment. Acta Horticulturae, No. 934, pp. 31-40.

Kitinoja, L., Sunil, S., Roy, S. K., and Kader, A. A. (2011). Postharvest technology for developing countries: challenges and opportunities in research, outreach and advocacy. Science of Food and Agriculture, 91(4) 597-603.

Medina, J., and Garcia, H. S. (2005). Pineapple: Post-harvest Operations. 28.

Mohammed, K., and Afework, B. (2016). Post-harvest loss and quality deterioration of horticultural crops in Dire Dawa Region, Ethiopia. Saudi Society of Agricultural Sciences, 17, 88-96, 9.

Mopera and Lotis, E. (2016). Food Loss in the Food Value Chain: The Philippine Agriculture Scenario. Developments in Sustainable Agriculture, 11: 8-16, 9.

Robert, E., Paull, N., Jung, C., and Parson, S. (2017). Pineapple harvesting and postharvest handling. 1.

Saeed, A., Farhan, U. H., and Khan, S. N. (2010). Post-harvest losses of tomato in markets of district Lahore. Mycopath, 8(2) 97-99.

Sromona D. (2017). Bromelain from Pineapple: Its Stability and Therapeutic Potentials. 260.

Steven, J. R. U., and Salesh, K. (2018). Postharvest Handling of Tropical Fruits in The South Pacific. 9.

TFNetl. (2011). Pineapple: Post-harvest and Processing. Retrieved from http://www.itfnet.org/v1/2016/05/pineapple-postharvest-processing/

Tsado, E. K. (2013). Removing the Field Heat of Pineapple Fruits and Its Effect on Shelf Life. European Journal of Agriculture and Forestry Research, 1, No.2, pp.16-25, 10.

Wijesinghe, W. A. J. P., and Sarananda, K. H. (2002). Post-harvest quality of 'Mauritius' pineapple and reasons for reduced quality., 5.

Yahaya, S. M., Mardiyya, A. Y. (2019). Review of Post-Harvest Losses of Fruits and Vegetables. journal of Science and Technical Research, 9. Retrieved from

Zaharan, H., Olaniyi, A., andFawole, U. L. O. (2019). Harvest and Postharvest Factors Affecting Bruise Damage of Fresh Fruits. Horticultural Plant, 6 (1): 1-13, 13. 